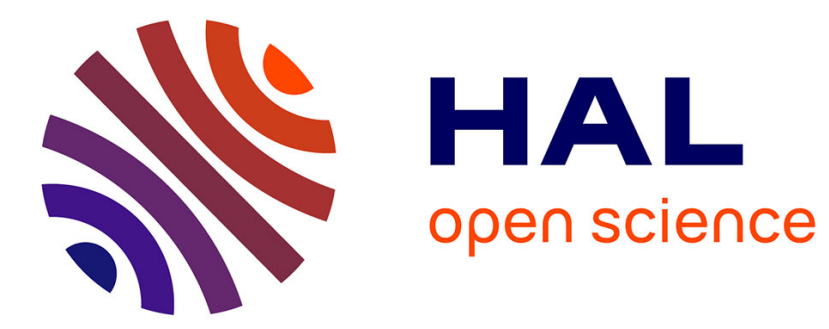

\title{
Feeling Gender Speak
}

Lorraine Nencel

\section{To cite this version:}

Lorraine Nencel. Feeling Gender Speak. European Journal of Women's Studies, 2005, 12 (3), pp.345361. 10.1177/1350506805054274 . hal-00571250

\section{HAL Id: hal-00571250 https://hal.science/hal-00571250}

Submitted on 1 Mar 2011

HAL is a multi-disciplinary open access archive for the deposit and dissemination of scientific research documents, whether they are published or not. The documents may come from teaching and research institutions in France or abroad, or from public or private research centers.
L'archive ouverte pluridisciplinaire HAL, est destinée au dépôt et à la diffusion de documents scientifiques de niveau recherche, publiés ou non, émanant des établissements d'enseignement et de recherche français ou étrangers, des laboratoires publics ou privés. 


\title{
Feeling Gender Speak
}

\section{Intersubjectivity and Fieldwork Practice with Women Who Prostitute in Lima, Peru}

\author{
Lorraine Nencel
}

DE VRIJE UNIVERSITEIT

\begin{abstract}
This article discusses a dimension of fieldwork methodology often overlooked. It concerns the act of feeling (inferences) and how this subjective ability contributes to understanding cultural meanings, which are unspoken or encoded in dialogue, but remain unarticulated. The discovery of this dimension in fieldwork eventually brought several epistemological principles into question pertaining to power and intersubjectivity subscribed to in a feminist or critical anthropology. Simultaneously, the use of this dimension in fieldwork gave insight into the relational construction of gender identity - the author's own, that of the women and a male assistant. The article illustrates this by reconstructing different ethnographic moments during fieldwork practice. Moreover, it aims to put these theoretical assertions into practice by presenting an ethnographic narrative intended to evoke meanings that contribute to feeling the construction of identity through interaction in fieldwork practice.
\end{abstract}

KEY WORDS feeling • feminist anthropology $\bullet$ gender identity $\bullet$ intersubjectivity $\checkmark$ power relations $\bullet$ prostitution

This article is a result of a dilemma I experienced during fieldwork on women who prostitute in Lima, Peru. The research was conducted in two different districts of Lima, where different types of prostitution ${ }^{1}$ were practised. During the day, I visited street prostitutes working in one of the oldest and poorest sections of Lima. At night, I hung out with street prostitutes in a plaza, and conversed with others working in a pick-up bar in a middle-class entertainment section. The first group of women were all nearing or above the age of 40 , the other group's age oscillated between twenties and mid-thirties.

To put it mildly, doing fieldwork on prostitution was tough. It was physically exhausting, emotionally trying, and the women were not

European Journal of Women's Studies Copyright (C) 2005 SAGE Publications (London, Thousand Oaks and New Delhi), 1350-5068 Vol. 12(3): 345-361; DOI: $10.1177 / 1350506805054274$ 
always cooperative. What was our relationship like? How can our communication be characterized? From my perspective our relationship can be described as difficult and taxing. Curiosity, an excellent attribute for an anthropologist, is not a virtue in this urban setting. When I brought up relevant research topics, a silence would fall or curt answers would be given, lies would be told. More often than not, the women would feed me bits of information when they felt like it. Interpreting our relationship from their perspective, it was probably very similar to their relationships with other outsiders. Very little is talked about, much is concealed or avoided and distrust reigns. Thus, I found myself in a fieldwork situation that was far from the anthropological ideal and to top it off, many of my questions were left unanswered. Still, if so little was verbalized, how did I manage to collect the material that coalesced into a book about their lives, the construction of gender identity and their marginalization as women and as prostitutes (Nencel, 2000, 2001)? Reflexive analysis aided in solving this enigmatic puzzle and revealed a multilayered process constituting the process of gathering and creating knowledge in the field.

In part, the material collected was found in a subterranean mode. Within this realm, silence acquires significance; meanings that remain unspoken, unsaid and untold are encoded in the actual dialogue. Expressions emerge from meanings created through shared but unstated knowledge. Gestures, tone and facial expressions amplify these meanings. In essence, these meanings are evoked in interaction. Some are expressed in doings and deeds but others are enclosed in the intentions behind what is being said and often conflict with what is actually said. Others are found in the silences or appear through a different reading of the same dialogue. Smith and Watson come to similar conclusions in their article on autobiographical narratives. They state: 'The narrative can be coded, signalling certain meanings while masking others before those not sharing the secret knowledge. Phrases or intonations or certain rhetorical gestures become veiled signals to other participants in the unspeakable' (Smith and Watson, 1996: 15). If these meanings cannot always be read straightforwardly by the researcher, how then are they identified and given substance in the research process and ultimately in the ethnographical text?

Here we enter into the terrain of methodology to discuss an aspect normally not treated as methodological, but, I contend, which accompanies everyone to the field and is essential for an ethical and reflexive anthropology. I refer here to the act of feeling and its influence in fieldwork.

Feeling has at least three dimensions. First, there are feelings as in emotions. Fieldwork can be experienced as pleasurable or unpleasant. Feelings of affection or antipathy towards a respondent may ultimately influence research results. Second, when something is felt an inkling or a 
suspicion emerges and this feeling is the impulse to dive deeper into the matter, giving the anthropologists the feeling of being a detective, following inferences until they make sense. This dimension of feeling is situated and is a result of fieldwork interactions and appears to work similar to what Lancaster calls 'the give-and-take of social life'. As something that

. . . is tentative, unarticulated, inarticulate. Meanings are negotiated: we don't quite know what we meant until a response comes from someone else. Our best thinking is serendipitous: we're not quite sure what we suspected until some evidence appears. We're not quite sure what we're looking for until we find it. A gaze roves until it catches something unexpected, as we might have expected. (Lancaster, 1997: 13)

Finally, and highly related to the previous, it also refers to the act of becoming aware, of being able to sense something. In this manifestation, feeling in fieldwork is receiving and perceiving meanings and emotions that are evoked and embodied. It can be compared with the attributes given to oral narrative by Patai. Patai conceptualizes oral narratives as follows: 'oral narratives usually evoke rather than describe emotions, in the same way they usually evoke rather than describe the cultural context with which speakers' lives are lived' (Patai, 1988: 148). Perhaps the difficulties I experienced in fieldwork made me more sensitive to the importance of feeling in gathering cultural expressions of gender (identity). If I had received all the answers verbally, I would not have been made aware of the unspoken. When I learnt to read unspoken, encoded messages, at times they made more sense than what was being said.

Conceptualizing the act of feeling as a methodological component in fieldwork reworks the western division between feeling and thinking, the emotional from rational and therefore raises queries concerning certain epistemological principles. Hilary Rose (quoted in Harding, 1986) associates the unification of thinking and feeling as a step towards a feminist theory of knowledge. 'Its distinctiveness is to be found in the way its concepts of the knower, the world to be known, and processes of coming to know reflect the unification of manual, mental and emotional ("hand, brain and heart") activity characteristic of women's work' (Harding, 1986: 142).

Unni Wikan discusses the Balinese ideal of 'feel-think', which stresses the inseparable unification of these two actions in Balinese thought. Those who separate them will be unable to reach genuine insights (Wikan, 1991: 285). Upon this discovery, Wikan questions the western social science tradition and concludes, 'What if Balinese are right that feeling-thinking is one integral process that should be implicated in any successful venture ... how then should we proceed methodologically to enhance the string of our knowledge?' (Wikan, 1991: 287). Further on she states, 'Our splitmind vision of culture, then, impedes understanding of alternative 
epistemologies like those based in feeling-thinking as vital premise and the key of relevance to lived experience' (Wikan, 1991: 289).

The act of feeling portrayed here is part of the multilayered process constituting knowledge construction in the field. It is entwined with more conventional methods relying on spoken statements. The relationship between the unspoken and the verbal is not a dichotomized separation. It resembles Wikan's 'feeling-think' conception in which it is difficult to discern where one leaves off and the other begins.

Methodologically, the act of feeling blooms in an intersubjective fieldwork relationship founded on reciprocity, partial identification and double consciousness (Mies, 1991: 78-9). Power differences are minimized and the researcher and research subject 'are assumed to be individuals who reflect upon their experience and who communicate those reflections' (Acker et al., 1991: 140) and produce knowledge together. Intersubjective interactions are not directed by research protocols that instruct the researcher to maintain distance and obtain rapport, but rather it is assumed that distance and approximation are negotiated and/or created in the fieldwork relationship. Thus, intersubjectivity does not erase the divide between researcher with her research objectives and the research subject who consents to participate in the project, nonetheless, in varying degrees it enables a special relationship to grow characterized by respect, mutual interest, humour, moments of friendship, trust and guided by feeling.

This article has two purposes, in the first place it aims to explore the relationship between intersubjectivity and feeling. In the following section, an analysis is made of the unspoken expressions felt in our interactions and in doing so challenges the previously stated assumptions regarding intersubjective fieldwork relations. The second purpose is to present an illustration of how the unspoken and untold expressions of gender are enacted in fieldwork and how I learnt to grasp meanings enacted in the interactions between myself, the women who prostitute and between the research subjects.

\section{SILENCES, DENIALS AND LIES}

During the preparation of the research proposal and upon leaving for the field, my anthropological identity could be most closely described as a standpoint feminist (Harding, 1986) with unorthodox methods, who, in regard to fieldwork, considered an intersubjective relationship the most appropriate, ethical and politically correct. Thus, in the field an attempt is made to create a relationship of dialogue. My objectives of research intended to de-objectify the prostitute by designing an investigation that studied their situations not only from the perspective of their work, but 
also as women situated in a broader community. I set out to the field with the intention to do life stories, which I considered reflected most adequately my epistemological standpoint and research objectives. In retrospect, I am still convinced of my good intentions even though the fieldwork did not reflect the progressive, accumulative scenario of gaining trust assumed in intersubjective fieldwork relations. What ensued was a continuous struggle between fieldwork reality and the ethical and epistemological principles I took to the field. In other words, there was no dialectical interaction (i.e. Mies, 1991), nor rarely was there a conversation that could be classified as dialogue (Dwyer, 1979; Schrijvers, 1991). What there was was a deafening silence. What did this silence tell? It revealed a great deal about power and the construction of identities.

\section{WHEN SILENCE BECOMES UNBEARABLY LOUD}

The silence I experienced brought into question the power relationships between the researcher and the research subject. As alluded to earlier, it is assumed that in the field all efforts will be made to minimalize power differences and create egalitarian relationships. However, this decision to construct an intersubjective relationship - has been taken by the researcher. The researcher assumes beforehand that both parties desire an egalitarian, harmonious relationship. It is not a joint decision or one necessarily reflecting the subject's yearning. Although such a relationship is less harmful than an asymmetrical one, the researcher still is the person who orchestrates the relationship. She does not relinquish the bandleader's baton and above all, still has the power to decide whether and when she will release it.

The researcher assumes she is in the powerful position. What does this power entail? The power to define the research project? The power obtained from class, culture or ethnic differences? If the anthropologist finds herself in a position of power because she is defining the terms of research and creates the situations of encounter, isn't it absurd to presume she defines and controls the entire relationship? Why does the projection of power in the field reflect a nearly binary opposition between the powerful and the powerless instead of departing from the multipositioned subject? Lerum asserts, 'Although researchers may still ultimately claim the most structural power, the immediate interpersonal power dynamic may be far more fluid, unpredictable, and weighted toward the researched. Thus, emotionally engaged researchers must continuously evaluate and construct the behaviour best suited for each person and situation' (Lerum, 2001: 475).

What happens in situations where the research subjects are not interested in an egalitarian relationship? For example, either they have no 
problems accepting the differences that exist and are not interested or do not feel comfortable in an egalitarian relationship, or inversely, which happens to be this case, the prostitutes were not interested in sharing power. They gave me no more than a minimal amount of space for manoeuvring and the control of the situation remained in their hands. Of course, I made efforts to negotiate alternative configurations of power relations. I attempted to build trusting relationships in which they would eventually feel comfortable enough to relate their life story. There is no denying, our relationships were founded on respect and a degree of trust, but this impasse in dialogue was never completely surmounted. They seemed content to hold onto the reins throughout the duration of fieldwork. Thus, the silence between us forced me to ponder to what extent the concept of intersubjectivity is ethnocentric, paternalistic and grounded in an essentialist notion of power.

The silence also embodies expressions of gender identity - theirs and my own. The control they exercised over our relationship showed how they managed and exerted power in their working lives. This sense of power that I felt in our daily interaction caused me to reflect on the conceptualization of prostitutes' identities encountered in feminist theory either as victims of sexual slavery, proposed by the abolitionist strand of feminist prostitution theory (Barry, 1995) ${ }^{2}$ or as sexually assertive women (Alexander, 1997), a symbol claimed by sex workers' rights advocates and academics. Both of these labels inaccurately portray the complexity of power and how it is exerted and exercised in daily practice.

The silence also projected certain features onto my gender identity. During my nightly adventures, a male assistant accompanied me. It did not take long to realize the differing ways the women related to us. They seemed at ease talking to him, they appeared to let their guard down and confided in him, while I felt they often kept their distance and held up a certain image for me.

In retrospect, I realize that during fieldwork I departed from an equivocal ontological notion that only one version of truth exists. Since my assistant received the type of information I wanted to hear, I was inclined to think his version was the truth and mine false. His relationship was less problematic than my own. He was a native of Lima, which made it easier for him to read between the lines, a skill that anthropologists must learn but takes some time to acquire. Returning from the field and reading over my notebooks several times, I became aware that the cause of the differing relationships was gender related. Roberto was able to appeal to the women using gender relations to his advantage. He was flirtatious and charming and they enjoyed the attention. This experience convinced me to question even further the positivist-oriented conception of scientific truth and inspired me to analyse the material as different gendered versions of the truth: one constructed in a gender relation between two 
women and the other between a man and a woman. Nonetheless, during fieldwork, this dilemma caused rich reflexive moments that gave insight into the process of gender construction in the world of prostitution.

There are various positions belonging to men in the nightlife. They are clients, husbands (maridos), pimps, managers, bouncers or waiters. Before the women got to know my assistant he was a potential client. When they became aware of his intentions, they continued to talk to him because he showed them respect, was interested in what they had to say and gave them affection. Many of the women trusted him, some wished they had a man like him. Two fell in love with him, and others appreciated his friendship.

There is no existing role for a woman who does not prostitute and it is even harder to imagine if she is a foreigner. It gradually became clear that our relationship constructed an image of me as a buena mujer (good woman) - an ambiguous but nonetheless, pervasive image. Their representation of me as a buena mujer shows their acceptance of a non-prostitute in their setting. The friend who does not look down on us, someone willing to help us, who does not compete. In other words, different from other women who do not prostitute.

The second connotation overshadows the first by highlighting class, ethnic and social difference. I was the professional, I had a love life, a gratifying life and being a foreigner it was assumed that I was financially well off. This second interpretation constructed barriers between us. For some I represented the type of woman they would like to be. Therefore, my presence was a reminder of the dreams and desires they were unable to achieve. This made them feel uncomfortable telling me their stories. Perhaps they did not consciously make this comparison, nonetheless, it was silently present. Either I was an exception to the run-of-the-mill good woman or on another level, I reflected this very same woman. Thus, the silence provoked by their projections of my gender identity functioned as a mirror that gave insight into their perceptions of their selves. They upheld the traditional Peruvian gender dichotomy of femininity, which constructs juxtaposed gender scripts - one as the good woman (the mother) and the other as the bad (the whore). Hence, if I was the good woman then indirectly within our relationship they positioned themselves as the bad.

Returning to the concept of power, these two manifestations of identity created different power relations. The first projection reinforced the relationship in which they managed and exerted power. In the second, by according me the stereotypical image of a woman who does not prostitute, I was regarded as more powerful and distance was maintained. Both configurations obstructed the knowledge process to some degree. Meanwhile, the relationship between my assistant and the women reflected male and female power relations in general and in this context in particular. 
Finally, all of this brought into question an assumption intricately woven into the notion of intersubjectivity, namely that female anthropologists are more equipped and find it easier to do research with women than a man. In other words, the commonalties experienced as being members of the same gender will ultimately override differences. Working with this premise increased the silence and obscured my vision to other conceivable relationships, not necessarily the epistemological ideal, but which would be based on mutual respect and other elements constituting the foundation of feminist methodology.

\section{DENIAL AND UNFURLING THE UNTOLD}

As I stated earlier, I had chosen to use life stories to complete my research objectives. In her discussion of feminist ethnography, Bell states, 'Feminist ethnography opens a discursive space for the "subjects" of the ethnography and as such is simultaneously empowering and destabilizing' (Bell, 1993: 31). One of the methods to create this discursive space is through life stories. Moreover, life history methodology enables the growth of intersubjective fieldwork relations. For this and other reasons, for example the rich and subtle details that flow out of a life story, I was determined to use life stories as my primary source. Little did I know this would prove almost impossible. During fieldwork, I collected five interviews. Two resembled interrogations and the other three bear a strong resemblance to life stories. Other than these five interviews, I was unable to collect life stories and relied heavily on my participant observation in the field to fill in the details and help make sense of cultural meanings. What does this form of silence imply and what does this suggest about intersubjectivity and research aimed to empower and to reduce asymmetrical relationships? ${ }^{3}$ Suzanna eloquently answers these questions in a few simple sentences.

I have left the past behind me. I don't want to think about it, I don't want to think about the future, I just live for today. I don't want to think about it because I don't want to recognize how I earn my money, I earn my money in an ugly way.

Doing a life story would force the women to recognize what they are doing and accept it as something more permanent. A life story can function as a catalyst that forces them to come to terms with the way they earn a living, which the majority of the women would rather avoid doing. And a life story creates a dimension of permanence, which in their enactments as prostitutes they try at all costs to avoid.

Many prostitutes dream of getting out as soon as possible. They experience prostitution as temporary and live within an illusion of continual 
temporality by planning the moment of retirement either in material terms - 'when I have saved enough money', 'when I am able to start my own business', 'when I am able to finish my house' - or in temporal expressions - 'four more years then I will quit', 'when I turn 30 I will leave'. Perhaps the desire to get out does not match their reality but it is what keeps them going. Thus, women who prostitute create a situation in which permanence is avoided, and anonymity is savoured creating the sensation they can slip away without many questions being asked or without being noticed. An anthropologist who is prepared to ask questions, to dive deeper and try to make sense of things is creating permanence. Thus, the notions of temporality and permanence were continually at odds.

Considering all of this, it should not come as a surprise that the majority of the women were not interested in doing life stories. Their various ways of refusing to do a life story were simultaneously expressions of denial of what they do and the permanence in which they do it. The clearest statement made was when they did not show up for an appointment. Life stories may be a way of sharing power, but the question remains whether life stories as a method of empowerment is boundlessly suited for all situations. This manifestation of silence suggests the need to evaluate at different moments of the research process the methodology being used and more specifically the use of life stories.

\section{READING BETWEEN THE LIES}

Lying is another form of silence. It contributes to creating an ambience of temporality and evasiveness and is also a way of managing information. In most cases, it is not meant to be a personal affront, nor should each lie be looked at as something to be unravelled. Sometimes, lies are never discovered. Being lied to during fieldwork drove me crazy, still, I did not always set out to find the truth. I listened to what was being said and tried to interpret the message being transmitted.

I was told on several occasions that lying soothes, makes one immune in this hard world, it kills curiosity. Thus, lying glosses over what they are doing and makes it easier to sustain a stance of non-acceptance in regard to their work. At the same time it offers protection.

Lying is the enactment of a double life. They are willing to conceal parts of their lives and carry this burden because of the shame they feel working as prostitutes and would be made to feel if it became known to others. Many of the women working at night concealed their work from their families. Some women hinted they are involved in an illegal activity such as drugs or counterfeit money (this would account for their having so much money). 'I would rather they think I am involved in something 
illegal than they find out how I really earn my money.' Even when the family suspects, the women continue to create borders between the two worlds to protect their private lives. Lying is a pragmatic decision. It is a protective coating intended to keep strangers out of their personal lives. Telling the truth can ultimately be used against them and could have severe repercussions in their private lives.

A refined lie I encountered is what I came to call a 'grand narrative': a believable account about some aspect of a person's life is brought into question after hearing more or less the same believable story from several people. An example of this is the women's motives to enter the trade. They maintained that sexual harassment by their previous employer was the push factor to enter prostitution. They all said something to the effect of 'if I am going to do it then why not be paid for it and make good money'. I am not underestimating the degree of sexual harassment that takes place on the work floor in Peru. On the contrary, more and more complaints are being published in the newspapers. However, it becomes less credulous in this context, when each time almost the exact words were used, in approximately the same place in the conversation and the subject was never brought up or referred to again.

Many women who work as prostitutes are aware of the accepted parameters for being a prostitute. In other words, they are aware of the 'correct' reasons for becoming a prostitute and they give clients what they want to hear. Thus, childless prostitutes are made into instant mothers; they always work with condoms and have regular check-ups. Lying serves to protect, to negate, to fantasize and to be accepted. It is a means to sculpture one's identity. Lal interprets silences and misinformation in the interviews as a form in which

... research subjects shape their own presentations ... The fact is that our subjects are often not just responding to our agendas and to our questions, but they are also always engaged in actively shaping their presentations to suit their own agendas of how they wish to be represented. (Lal, 1996: 204)

Lying is the most intentional performance of the prostitute. A simple lie constructs identity.

This account on research relations and the meanings they construct in the field has given an idea as to the messages concealed in the silences, the denials and lies and has cautiously delineated the contours they groove into gender identity. In addition, it has shown how these same silences challenge epistemological principles wrapped up in the concept of intersubjectivity. They have shown the intricate and inseparable relationship between interactions, epistemology and the production of cultural (gender) meanings in the field. Although I have managed to express this on paper, it is actually an outcome felt in the relations. Cultural meanings 
and understandings are also transmitted through this unspoken mode and it is the job of the researcher to capture them and try to make sense of them. In the following section, the ethnographic account illustrates how feeling enhanced understanding of cultural meanings during fieldwork.

\section{A JOB LIKE ANY OTHER: THE UNSPOKEN POWER OF PROMISCUITY}

'A job like any other' is an unsolicited statement I continually heard when the women described their work. It is a simple assertion packed with unarticulated meaning. It clarifies their position towards their work - a not out of the ordinary job that has nothing to do with sex. Taken at face value, this statement could be interpreted as an expression of a professional consciousness. However, this is not exactly the case. This statement is intended to counteract the promiscuous nature given to women in the social identity of the prostitute. In societies like Peru, being a prostitute is synonymous with being promiscuous. Thus, when the women say it is a 'job like any other', they are negating this dimension of their social identity. It took me some time to suss out the actual meaning of this statement. To understand how this unarticulated message finally came to the surface, it is necessary to examine the definition of prostitution I upheld when I came to the field.

My politically sound definition sees prostitution as a type of work if not a profession and negates any correlation between personal characteristics and the nature of the work. In this definition, promiscuity does not exist. This ethically correct stance towards prostitution echoes developments in the international sex workers' movement; however, during fieldwork it blinded me to the pervasive, unspoken notions of promiscuity embedded in their self-representations. ${ }^{4}$ Their statements stressed the non-existence of their own sexuality in their work. The idea that sexuality is a part of being a prostitute and that promiscuity has signifying power in the women's self-definitions is both verbally and non-verbally rejected. Initially, I took statements like 'I do it for the money' at face value because it seamlessly connected with my own definition of prostitution. It was some time before I realized that such a statement shrouds denials of promiscuity, understood by insiders because it is shared unstated knowledge. As we see later, this awareness came as a result of being able to be present where interactions took place, enabling me to feel what was going on behind what was actually being said.

The Plaza Bolivar, where the fieldwork took place, is well kept, lined with restaurants and very popular in the Limenian nightlife. Shortly after I started to visit the Plaza, my assistant introduced me to a young woman called Carmela, whom I was told is studying medicine and has five 
children. It was through Carmela and her colleagues that I began to realize the prominent positioning of promiscuity in their self-definitions. One of the areas where its presence was felt strongly was in their relations with their partners. Their partner's behaviour was extremely important in erasing promiscuity from their identities. Carmela's relationship with her boyfriend illustrates the layered complexity of this process of signifying.

Carmela had a stormy relationship with Miguel, her 'marido' ('husband'). He was married and had five children, who she claimed he had abandoned for Carmela. She described the meaning of her relationship as follows, 'the life I lead is tough. When you finally meet someone who truly loves you, you have to hold on to him the best you can.' Miguel made it known that he did not want Carmela working in his presence. If he suspected she had been working he would demonstratively walk away angry. If someone approached her when he was in the vicinity he would pass her a disapproving glance. Carmela explained, 'He does not want me to work when he is here. He gives me money on those nights, a little but it is money. It's all right; I have steady clients on the other nights. Some women give money to their boyfriends, I don't.' She implied these women kept the men and the men were cafiches (pimps). The significance of this statement would only become clear as fieldwork progressed.

Miguel's marital status was not a problem. Being attached does not necessarily influence the decision to get involved in a relationship, although there was always a lurking fear that he would return to his wife. Carmela never admitted openly she suspected he went back to visit his wife and children, it would make her relationship less genuine and more likely to be considered by others as an insignificant relationship that illustrates her promiscuity. To avoid this reaction and to kill curiosity when her boyfriend had vanished from the scene for a few days, she would say he went somewhere else to work. However, these words encoded her fears that her marido had permanently left her. The undertone of these statements remained unspoken. I coincidentally captured the other meaning when her boyfriend returned and I curiously asked him where he had been working. His muddled reply made me feel that there was more underlying his answer.

A prostitute's relationship is continually being scrutinized whether it is 'authentic'. All too often I heard people surrounding the women say, 'if he really loved her then he would not let her do this'. Thus, their partner's love is always in question. Outsiders define men de facto as pimps until proven otherwise. One of the worst things to say or imply is that a woman keeps her marido. This infers she not only works as a prostitute but she is a prostitute: a promiscuous woman. This in turn makes her relationship inauthentic. In the ambiente (the nightlife scene) the partner's identity can shift between being a marido or cafiche, according to how the man reacts 
and behaves in regard to his girlfriend's work. Subsequently, promiscuity is mediated through his behaviour. Carmela's relationship with Miguel illustrates this even further.

Miguel's insistence that Carmela did not work when he was present reinforced the idea that he was her marido. His obstinacy demonstrated that he was a man of principles, even though he never could have made enough money to support Carmela, her children and his own family. His jealous outbursts legitimized both their identities. Carmela even stopped working for a period when they attempted to live together. They would come together to visit the Plaza and spend some time with their friends, but as soon as a possible client approached her Miguel sternly told her to ignore him. Then one day, Carmela went back to work, but this time Miguel accepted she worked because he had lost his job. He waited for her in the park until it was time to pick her up to go home.

Carmela's return to prostitution was completely understandable. However, Miguel's versatility with regard to Carmela's work was not only surprising but questioned by others. Cati, a friend and colleague of Carmela's, ran into Miguel and told him what she thought of his change. 'You were different when you were working. You have five children, you can't just forget about them.' I interrupted and said, 'Carmela has several too.' She replied, 'Carmela only has one from a drug addict who she kept even worse than Miguel. After him it was a watchman who worked at the Plaza. It was the same type of relationship. Someone who lets you work in this doesn't really love you. Miguel should be working. He has five children. But he lost his job for some stupid reason.' She replied in disbelief, 'He lost his job because he didn't show up for four days, Carmela persuaded him not to go to work.' Thus, it was not only Miguel's behaviour that made him into a cafiche, but she strongly implied that Carmela always kept him as she was accustomed to do with all her boyfriends. Thus, Cati redefined Carmela as a 'common street whore', and inadvertently as a promiscuous woman. Miguel's resignation with the situation challenged his image as the caring marido and transformed him into a cafiche, putting the genuine nature of their relationship into doubt and tacitly reinforcing its promiscuous nature. A cafiche is a poor excuse for a man and is looked down upon. Miguel's attitudes and behaviour towards Carmela's work defined his identity and indirectly hers. The crux defining this notion of masculinity in this ambiente is not what stereotypically defines a pimp: a man who forces women to prostitute or has several women under his control. In this ambiente, this type of cafiche is nearly non-existent. It is not violence or force determining the definition, rather it is the fact that in an emotional relationship he accepts money earned from selling sex.

For a relationship to be labelled genuine (not promiscuous), based on love and not on opportunism, the man must aspire to remove his partner 
from the environment. In essence, he is responsible for remaking the women's gender identity to conform to traditional gender 'roles'. The man is expected to provide for her and her children and the woman becomes the housewife. In the realm of prostitution, this ideological illusion, and I deliberately call it an illusion because the majority of the relationships in the popular classes cannot even attempt to live up to this ideal, is strived for against all economic odds: the high level of unemployment and a minimum monthly wage that is not sufficient to satisfy a family's basic needs. Taking a woman out of the environment rearranges her sexuality. Previously accessible to all men willing to pay the price, ideally it is transformed into a sexuality exclusively practised with her partner. His acts must show that he is erasing the notions of promiscuity from her identity. The proof of the relationship's authenticity is determined by whether these goals can be successfully achieved. This is not merely an expression of wishful masculine thinking, the women share and contribute to this ideal, too. Sometimes it is even accomplished.

In worded expressions, the women who prostitute are reaching or holding on to the traditional gender norms. However, in the unspoken domain they are enacting and embodying their rejection and denial of promiscuity. Thus, the acceptance that a relationship is only authentic when the prostitute is removed from the ambiente infers that the act of selling sex is not just a way of making money but also a way to soothe her promiscuous desires. Attempts are made to limit its influence in the definition of oneself as a prostitute, but nonetheless, it possesses a forceful defining power. These unspoken notions of promiscuity became even more audible in how it was used by the women to define each other.

Returning to Carmela and Cati, Carmela presented a different version of the story. She claimed they had argued because Cati made a pass at Miguel when they stayed at her house. She admitted that Cati publicly called Miguel a cafiche, which she felt she had no right to say publicly, but her main explanation for their argument was Cati's sexual overtures to Miguel.

In these arguments, the notions of promiscuity constituting social definitions of the prostitute are projected onto the social setting to define the women's identity. On various occasions, I witnessed and was even involved in an argument that projected onto other women the promiscuous nature entangled in the label of the whore. By doing so, they become the mirror image - the woman who in her non-professional relationship enjoys an exclusive sexuality, thereby severing this aspect of their work from their private lives and coming closer to conforming to the gender ideal. Equally significant is how notions of promiscuity are denied or asserted, depending on the label given to the women's partner. All of this came together piecemeal, by being present in the field at different moments, in different situations, bringing the meanings to the surface in an act that combines thinking with feeling. 


\section{SOME FINAL REMARKS}

The recognition that feeling and thinking are much closer than usually assumed in fieldwork has been part of the process of deciphering the unsaid and making cultural sense of it. In the first part decoding the silences between the researcher and research subjects led to questioning epistemological principles and ethics of feminist anthropology and more particularly the concept of intersubjectivity and its correlating methods. This in turn gave insight into silent ways that identity was constructed and power relations figured in the field - between myself as a researcher and a non-prostituting woman, the women who prostitute and men visa-vis my research assistant. In the narrative excerpts presented in the second part, feeling in all its complexity facilitated reading what is usually left unread and unsaid in interaction and gave clues concerning cultural meanings of masculinity, femininity and sexuality in this particular setting. Through these readings of the fieldwork material, intersubjectivity has not lost its value in feminist research but rather its content has been expanded. Intersubjectivity is all too often portrayed as an ideal state. However, this study has shown that it is a relation that is workable, enabling and obstructive, as are all relations in the activities of daily life.

\section{NOTES}

1. The use of the word prostitution and prostitute instead of sex worker is intentional. It reflects how the women labelled their work and themselves. The women never referred to themselves as sex workers or to their work as sex work. It is feasible that in the last few years with the growth of a sex workers' organization in Lima this has changed.

2. That force does come into play in some women's experiences in prostitution goes without saying. But Barry constructs theories and strategies based on the supposition that prostitution is sexual slavery for all women who prostitute.

3. Additionally, as Wolf points out in referring to Spivak's writings, the notion of 'letting women speak' suggests 'that First World feminists are once again wielding their hegemonic power to allow Third World subjects an audience' (Wolf, 1996: 26).

4. The concepts of social representation and self or subjective representation of identity are borrowed from Moore (1994). For further discussion of these concepts in relation to women who prostitute, see Nencel $(2000,2001)$.

\section{REFERENCES}

Acker Joan, Kate Barry and Johanna Esseveld (1991) 'Objectivity and Truth: Problems in Doing Feminist Research', pp. 133-53 in M.M. Fonow and J.A. Cook (eds) Beyond Methodology: Feminist Scholarship as Lived Research. Bloomington: Indiana University Press. 
Alexander, Priscilla (1997) 'Feminist, Sex Workers and Human Rights', pp. 83-97 in June Nagle (ed.) Whores and Other Feminists. New York: Routledge.

Barry, Kathleen (1995) The Prostitution of Sexuality: The Global Exploitation of Women. New York: New York University Press.

Bell, Diana (1993) 'Yes Virginia There is a Feminist Ethnography', pp. 29-43 in D. Bell, P. Caplan and W. Jahan Karim (eds) Gendered Fields: Women, Men and Ethnography. London: Routledge.

Dwyer, Kevin (1979) 'The Dialogic of Ethnology', Dialetical Anthropology 4(2): 205-24.

Harding, Sandra (1986) The Science Question in Feminism. Ithaca, NY: Cornell University Press.

Lal, Jayati (1996) 'Situating Locations: The Politics of Self, Identity and "Other" in Living and Writing the Text', pp. 185-214 in D. Wolf (ed.) Feminist Dilemmas in Fieldwork. Boulder, CO: Westview Press.

Lancaster, Roger (1997) 'Guto's Performance: Notes on Transvestism of Everyday Life', pp. 9-32 in D. Balderston and D.J. Guy (eds) Sex and Sexuality in Latin America. New York: New York University Press.

Lerum, Kari (2001) 'Subjects of Desire: Academic Armor, Intimate Ethnography, and the Production of Critical Knowledge', Qualitative Inquiry 7(4): 466-83.

Mies, Maria (1991) 'Women's Research or Feminist Research? The Debate Surrounding Feminist Science and Methodology', pp. 60-84 in M.M. Fonow and J.A. Cook (eds) Beyond Methodology: Feminist Scholarship as Lived Research. Bloomington: Indiana University Press.

Moore, Henrietta (1994) A Passion for Difference. Cambridge: Polity Press

Nencel, Lorraine (2000) Mujeres que se prostituyen. Género, identidad y pobreza en el Perú. Lima: Ediciones Flora Tristán.

Nencel, Lorraine (2001) Ethnography and Prostitution in Peru. London: Pluto Press.

Patai, Daphne (1988) 'Constructing a Self: A Brazilian Life Story', Feminist Studies 14(1): 143-66.

Schrijvers, Joke (1991) 'Dialectics of a Dialogical Ideal: Studying Sideways and Studying Up', pp. 162-79 in L. Nencel and P. Pels (eds) Constructing Knowledge. London: Sage.

Smith, Sidonie and Julia Watson (1996) 'Introduction', pp. 1-24 in S. Smith and J. Watson (eds) Getting a Life: Everyday Uses of Autobiography. Minneapolis: University of Minnesota Press.

Wikan, Unni (1991) 'Towards an Experience-Near Anthropology', Cultural Anthropology 6(3): 285-306.

Wolf, Diana (1996) 'Situating Feminist Dilemmas in Fieldwork', pp. 1-55 in D. Wolf (ed.) Feminist Dilemmas in Fieldwork. Boulder, CO: Westview Press.

Lorraine Nencel is assistant professor at the Department of Social Research Methodology, Vrije Universiteit, Amsterdam, The Netherlands. As an anthropologist, she has always been interested in methodological and epistemological issues. She has specialized in the subjects of gender (masculinity and femininity), sexuality and identity in relation to the subjects of homework, prostitution and secretaries in public administration all in Lima, Peru. Publications include Constructing Knowledge: Authority and Critique in the Social Sciences, with P. Pels (London: Sage, 1991) and Ethnography and Prostitution in Peru (London: Pluto Press, 2001). Currently, she is developing a comparative new project concerning the significance of money in the construction of gender, class and ethnic 
identity. She is a member of the advisory board of the Global South, Mama Cash and does methodological consultancy and training for NGOs. Address: Department of Social Research Methodology, De Vrije Universiteit, De Boelelaan 1081c, 1081 HV Amsterdam, The Netherlands. [email: LS.Nencel@fsw.vu.nl] 